\title{
PKM Penanggulangan Hama Kutu Kebul Pada Cabai Rawit Menggunakan Perangkap Likat Kuning di Desa Ayuhula Kabupaten Gorontalo
}

\author{
Zulham Sirajuddin $^{l)}$, Evie Adriani ${ }^{2)}$ \\ ${ }^{12)}$ Universitas Ichsan Gorontalo, Gorontalo, Indonesia \\ Corresponding Author: Zulham Sirajuddin, zulham.sirajuddin@gmail.com
}

\begin{abstract}
Abstrak: Hama kutu kebul merupakan salah satu persoalan yang cukup sering terjadi di Kabupaten Gorontalo. Minimnya pengetahuan petani cabai rawit mengenai hama kutu kebul merupakan salah satu sebab banyaknya hama kutu kebul yang menyerang tanaman cabai rawit maupun hortikultura lainnya. Fokus utama kegiatan ini adalah menjawab persoalan kutu kebul pada cabai rawit melalui pemantauan secara partisipatif melalui pendekatan citizen science. Tujuannya adalah untuk meningkatkan skill dan pengetahuan petani mengenai pemantauan, pencegahan, serta pengendalian hama kutu kebul pada cabai rawit. Kegiatan ini menggabungkan dua aspek, dimana aspek pertama adalah kegiatan peningkatan kemampuan petani dalam pemantauan, pencegahan, dan pengendalian hama kutu kebul, dan aspek kedua yaitu pemantauan partisipatif berbasis citizen science. Kegiatan ini terlaksana dalam bentuk pelatihan tiga sesi, dimana sesi-1 yaitu mengenai pengenalan hama kutu kebul termasuk ciriciri serta penanggulangannya. Lalu pada sesi-2, yaitu praktek pembuatan dan pemasangan alat perangkap yellow sticky trap, dimana petani mempelajari cara membuat perangkap hama kutu kebul. Kemudian pada sesi-3, peserta belajar mengenai prosedur field work, yakni pengamatan, pencatatan, serta input data. Kegiatan ini memberikan pemahaman kepada petani mengenai pentingnya penggunaan perangkap kuning, serta keterampilan kepada petani agar dapat membuat dan menggunakan perangkap kuning sehingga mengurangi serangan hama. Sebelum kegiatan, petani belum mengetahui bahwa mereka dapat membuat sendiri perangkap sederhana dengan menggunakan bahan yang mudah ditemukan disekitar dan memberikan dampak yang baik bagi tanaman mereka. Setelah kegiatan ini, petani menyadari pentingnya pemantauan hama dan juga memahami cara pembuatan perangkap untuk menanggulangi hama kutu kebul sehingga hasil panen dapat dimaksimalkan.
\end{abstract}

Kata Kunci: citizen science, kutu kebul, pengendalian hama, perangkap likat kuning

Abstract: Whitefly pestsattack is a common problem in Gorontalo. The lack of knowledge of cayenne pepper farmers about eliminating whitefly pests is one of the reasons for the whitefly pests attack on cayenne pepper and other horticultural crops. The main focus of this activity is to practice participatory monitoring through the citizen science approach. The aim is to increase farmers' skills and knowledge regarding monitoring, prevention, and control of whitefly pests in cayenne pepper. This activity combines two aspects, where the first aspect is the activity of increasing the ability of farmers in monitoring, preventing and controlling whitefly pests, and the second aspect, namely participatory monitoring based on citizen science. This activity is carried out in the form of three training sessions, in which session-1 is about the introduction of whitefly pests including their characteristics and their prevention. Then in session 2, the practice of making and installing yellow sticky trap traps, where farmers learn how to make whitefly pest traps. Then in the 3rd session, participants learned about field work procedures, namely observation, recording, and data input. This activity provides farmers with an understanding of the importance of using yellow traps, as well as skills for farmers to make and use yellow traps to reduce pest attacks. After this activity, farmers realized the importance of pest monitoring and also understood how to make traps to combat whitefly pests so that yields could be maximized. 


\section{Pendahuluan}

Kabupaten Gorontalo merupakan wilayah penghasil cabai rawit dengan produksi mencapai 66,8 ribu ton pada tahun 2018. Cabai rawit Malita FM merupakan varietas yang dikembangkan sebagai produk unggul di Gorontalo sejak tahun 2008. Produksi cabai rawit segar dengan tangkai tahun 2014 sebesar 117.719 Kuintal. Dibandingkan tahun 2013, terjadi penurunan produksi sebesar 10.105 Kuintal (-7,91 persen). Penurunan ini disebabkan oleh menurunnya produktivitasnya sebesar 3,54 Kuintal per hektar (-6,36 persen) dan juga berkurangnya luas panen sebesar 38 hektar (-1,66 persen) dibandingkan tahun 2013 (BPS Gorontalo, 2019). Komoditas cabai rawit termasuk salah satu komoditas yang sangat fluktuatif mengikuti mekanisme pasar (Indriani dkk, 2020). Viana, Hartono dan Waluyati (2017) berpandangan bahwa volatilitas harga cabai rawit di tingkat produsen dipengaruhi oleh fluktuasi harga cabai rawit produsen satu bulan sebelumnya.

Salah satu kecamatan penghasil komoditas pertanian adalah Kecamatan Dungaliyo, sebuah wilayah yang terletak sekitar $22 \mathrm{~km}$ di sebelah selatan Kota Limboto. Luas Kecamatan Dungaliyo adalah $72,75 \mathrm{~km} 2$, dimana sebagian besar merupakan dataran rendah dan sebagiannya lagi merupakan area pegunungan. Di Kecamatan Dungaliyo, Desa Ayuhula merupakan salah satu desa terbesar dengan luas sekitar 13,68 km2. Lokasi Desa Ayuhula terletak sekitar $3 \mathrm{~km}$ dari ibukota kecamatan yakni Botuboluwe. Desa Ayuhula merupakan salah satu penghasil komoditas hortikultura seperti cabai rawit dan tomat. Terdapat beberapa kelompok tani cabai rawit di Desa Ayuhula yang aktif menanam dan panen setiap tahun. Salah satu kelompok tani tersebut adalah Kelompok Tani (KT) Huyula yang beranggotakan petani yang menanam beragam komoditi strategis andalan Kabupaten Gorontalo termasuk cabai rawit. Di kelompok ini, terdapat 10 anggota yang menggantungkan hidup keluarga pada hasil panen cabai rawit, dengan luas lahan keseluruhan tanaman cabai rawit adalah $3 \mathrm{Ha}$.

Salah satu persoalan yang dihadapi oleh petani cabai rawit yang tergabung dalam KT Huyula adalah serangan hama kutu kebul (Bemisia tabaci) yang berperan sebagai hama dan vektor atau pembawa virus kuning (pepper yellow leaf curl) atau virus gemini pada tanaman cabai rawit. Hasil wawancara dengan petani dan observasi langsung ke lahan petani menunjukkan bahwa sempat beberapa kali terjadi kegagalan panen akibat keberadaan hama kutu kebul tersebut. Petani KT Huyula memaparkan bahwa setiap tahun sering terjadi serangan hama kutu kebul pada cabai rawit yang mereka tanam. Pada tahun 2018 misalnya, serangan hama kutu kebul menghinggapi sekitar 4.000 pohon cabai rawit yang mereka tanam sehingga mengganggu produksi hingga 0,5 hektar luas lahan cabai rawit mereka. Hal ini berakibat pada penurunan hasil panen cabai rawit yang cukup drastis sehingga merugikan petani. Hama kutu kebul memang kerap menyusahkan petani cabai rawit di Indonesia. Tuhumury dan Amanupunyo (2018) melaporkan bahwa petani cabai rawit di Desa Waimital, Kecamatan Kairatu, bahkan sampai harus mengalami kerusakan hingga $42 \%$ tanamannya akibat kutu kebul.

Serangan hama kutu kebul sangat berpotensi menghambat produksi cabai rawit sehingga berdampak pada perekonomian petani cabai rawit maupun masyarakat umum. Kegagalan panen berdampak pada penurunan pendapatan yang drastis oleh para petani mitra sebab jumlah jualan berkurang. Dampak lebih jauh, kelangkaan cabai rawit terjadi di pasar tradisional akibat kegagalan panen yang berpotensi membuat harga cabai melonjak. Hal ini berdampak pada kerugian industri makanan maupun masyarakat umum yang mengkonsumsi cabai rawit seharihari. Gejala keberadaan kutu kebul dapat diamati pada bagian bawah daun cabai, yaitu terdapat populasi kutu kebul yang berwarna putih dan menghisap jaringan daun cabai serta membawa 
virus kuning. Adapun gejala kerusakan yang ditimbulkan yaitu terjadi perubahan bentuk dan warna pada daun cabai seperti mengeriting dan berwarna kuning akibat kerusakan sel pada daun. Hama kutu kebul dapat menghambat pertumbuhan tanaman cabai hingga pada titik kritis, bisa berdampak pada gagal panen. Akibatnya, harga cabai rawit cukup melonjak di pasaran lokal.

Minimnya pengetahuan petani cabai rawit mengenai hama kutu kebul merupakan salah satu sebab banyaknya hama kutu kebul yang menyerang tanaman cabai rawit maupun hortikultura lainnya seperti tomat. Menurut petani KT Huyula, petani mengalami kesulitan dalam memantau dan menanggulangi hama kutu kebul pada tanamannya. Akibatnya, petani hanya mampu mengetahui bahwa terdapat hama kutu kebul pada tanaman cabai rawit yang mereka budidayakan setelah tanaman tersebut terserang. Meski secara akademik, terdapat beberapa cara pemantauan, pencegahan maupun pengendalian hama kutu kebul, informasi seperti itu belum diketahui dan dipahami oleh petani cabai rawit KT Huyula. Keterbatasan akses terhadap informasi tersebut merupakan salah satu permasalahan yang dialami oleh KT Huyula. Pemantauan hama Kutu Kebul penting dilakukan sebelum terjadi hambatan pertumbuhan tanaman cabai rawit, hal tersebut dikarenakan seluruh stadia dari hama kutu kebul terletak pada bagian bawah daun cabai rawit. Selain itu, hama kutu kebul memproduksi kotoran yang disebut embun madu yang mampu mengundang fungi dalam hal ini disebut embun jelaga. Embun jelaga mampu menghambat proses fotosintesis dari daun tanaman cabai. Sehingga selain menghisap jaringan floem daun cabai, hama kutu kebul secara tidak langsung juga mampu mengakibatkan sulitnya tanaman cabai untuk berfotosintesis sehingga terjadi penurunan produksi dari cabai rawit.

Berdasarkan pertimbangan tersebut, diperlukan kegiatan untuk meningkatkan pengetahuan petani serta keterampilan penanggulangan hama kutu kebul. Terdapat beragam cara untuk menanggulangi serangan hama kutu kebul. Diantaranya yaitu dengan penggunaan ekstrak daun tithonia sebagai pestisida nabati (Susanti, Widyastuti \& Sulistyo, 2015). Di Sri Lanka, petani menggunakan tanaman penjaga (crop protection) untuk mencegah serangan kutu kebul secara ramah lingkungan (Prasannath, Dharmadasa, Menike, \& De Costa, 2020). Penelitian ini menggunakan perangkap likat kuning (yellow sticky trap) sebagai upaya pengendalian hama kutu kebul pada cabai rawit. Kegiatan ini merupakan kegiatan pengabdian pada masyarakat dalam skema Program Kemitraan Masyarakat (PKM). Fokus utama kegiatan ini adalah menjawab persoalan kutu kebul pada cabai rawit melalui pemantauan secara partisipatif melalui pendekatan citizen science. Tujuannya adalah untuk meningkatkan skill dan pengetahuan petani mengenai pemantauan, pencegahan, serta pengendalian hama kutu kebul pada cabai rawit.

\section{Metodologi}

Kegiatan ini menggabungkan dua aspek, dimana aspek pertama adalah kegiatan peningkatan kemampuan petani dalam pemantauan, pencegahan, dan pengendalian hama kutu kebul, dan aspek kedua yaitu pemantauan partisipatif berbasis citizen science. Dalam kegiatan peningkatan kemampuan petani cabai rawit, dilakukan pelatihan peningkatan kapasitas petani dengan materi sebagai berikut:

\section{A. Pemantauan.}

Pemantauan perlu dilakukan oleh petani cabai rawit dengan mengetahui ciri-ciri morfologi dari setiap tahapan atau stadia kutu kebul. Dengan begitu, petani dan kelompok tani dapat melakukan langkah taktis dan strategis untuk mencegah serta menanggulangi hama 
tersebut. Pada pelatihan ini, petani diajarkan untuk mengenali ciri-ciri hama kutu kebul, serta fenomena-fenomena yang berpotensi membuat keberadaan hama tersebut mewabah.

\section{B. Pencegahan dan Pengendalian.}

Pencegahan dilakukan salah satunya dengan cara menyediakan musuh alami. Salah satu cara biologis adalah dengan mempersiapkan parasitoid kutu kebul dengan menanam tanaman yang menjadi tempat bernaungnya parasitoid tersebut. Misalnya serangga yang berperan sebagai hama dan musuh alami. Keanekaragaman hama dan musuh alami perlu diketahui sedari dini agar mampu ditentukan cara yang efektif yang perlu dilakukan. Pengendalian hama kutu kebul dilakukan dengan cara memasang perangkap untuk serangga dewasa/imago kutu kebul yakni perangkap kuning (yellow sticky trap). Penggunaan perangkap kuning dimaksudkan untuk memancing hama kutu kebul untuk hinggap pada perangkap. Mas'ud (2002), melaporkan bahwa warna kuning menarik perhatian dari serangga herbivora dikarenakan warna tersebut memberikan stimulus makanan yang disukai serangga. Hama akan menduga bahwa warna tersebut adalah daun atau buah yang sehat untuk dikonsumsi. Penggunaan likat kuning juga dianjurkan oleh peneliti pertanian sebab dapat mengurangi serangan hama pada cabai rawit, sebagaimana ditunjukkan oleh Andriani dan Yuniarsih (2020).

Dalam kegiatan PKM ini juga dilakukan kegiatan pemantauan partisipatif dengan model citizen science, yakni dimana petani terlibat langsung dalam kegiatan pemantauan secara scientific, berperan dalam mengetahui dan mengelola data tersebut, serta mampu menggunakan data pemantauan tersebut untuk penyusunan strategi. Dalam kegiatan ini, pelaksana bekerja sama dengan petani cabai rawit yang tergabung dalam KT Huyula sehingga bukan hanya dapat melakukan kegiatan pemantauan yang akurat tetapi juga melalui pemantauan berkala dengan model citizen science ini petani dalam kelompok mitra dapat memperoleh data dasar yang berkala mengenai potensi serangan hama kutu kebul sehingga dapat mengantisipasi hama tersebut pada musim berikutnya. Untuk memantau keberadaan hama kutu kebul yang seringkali merugikan petani cabai rawit, perlu dilakukan langkah-langkah yang strategis. Di satu sisi, monitoring keberadaan dan perkembangan hama kutu kebul perlu dilakukan melalui pemantauan yang ilmiah dan akurat. Disisi lain, pemantauan perlu melibatkan masyarakat utamanya petani sebagai pelaku utama. Pemantauan hama merupakan hal pertama yang perlu dilakukan dalam kegiatan pengendalian hama tanaman. Keberadaan hama dan musuh alami pada tanaman budidaya dapat dijadikan sebagai acuan dalam kegiatan pengendalian hama tanaman. Beberapa cara pemantauan yaitu melalui pengamatan secara langsung organisme yang terdapat pada ekosistem pertanaman cabai rawit.

Mengatasi hama kutu kebul akan lebih efektif dilakukan apabila keberadaan hama tersebut dapat dideteksi sedari dini bersama-sama, dimana langkah awal yang perlu dilakukan dalam pengendalian hama yaitu pemantauan yang mesti dilakukan tersistematis agar strategi untuk tindakan preventif dapat dirumuskan. Melalui pendekatan ini, masyarakat terdampak suatu kasus turut aktif melakukan kegiatan ilmiah dalam menemukan, memantau dan mengamati fenomena yang terjadi di wilayahnya. Pemantauan hama kutu kebul dalam kegiatan ini menggunakan metodologi citizen science, dimana petani sebagai masyarakat umum (citizen) terlibat secara scientific dengan tim akademisi dari Universitas Ichsan Gorontalo untuk bersama-sama melakukan kegiatan penelitian dalam monitoring populasi kutu kebul.

Citizen Science merupakan kegiatan ilmiah berbasis partisipasi masyarakat. Itu sebabnya, keterlibatan masyarakat merupakan unsur penting dalam kegiatan ini. Sebagai bagian dari kegiatan PKM ini, dilakukan pemantauan partisipatif dengan melibatkan petani cabai rawit, dengan tahapan pemantauan dengan model citizen science yang ditawarkan adalah: 
Pemantauan - Pencatatan - Rekapitulasi data - Analisis data - Kesimpulan. Kegiatan ini akan dilakukan secara bersama-sama selama 6 bulan. Adapun rekapitulasi data digunakan aplikasi Google Forms, sehingga data yang diambil dapat direkapitulasi otomatis.

\section{Hasil dan Pembahasan}

Pemberantasan hama kutu kebul mesti dilakukan secara terpadu. Terdapat cara mengatasi hama kutu kebul yakni melalui pengendalian hama terpadu (PHT) dengan memadukan berbagai taktik pengendalian dimulai dari awal penanaman hingga pemanenan. Oleh karena itu, tim pelaksana menyusun kegiatan pemantauan, pencegahan, dan pengendalian hama kutu kebul berbasis citizen science sebagai solusi permasalahan yang dihadapi petani cabai rawit. Adapun lahan yang ditangani berada di tiga lokasi dengan total luas lahan untuk pelatihan yaitu 0,25 Ha. Pemantauan hama melalui pendekatan citizen science merupakan hal baru di Indonesia. Meski begitu, di banyak negara-negara maju, sudah terdapat beberapa pengamatan hama melalui metode citizen science ini. Salah satunya adalah pilot project pemantauan hama dalam budidaya lebah yang dilakukan oleh Wageningen Environmental Research (WENR) yang merupakan bagian dari Wageningen University and Research Center (WUR), melalui project bernama INSIGNIA (Loglio dkk., 2019). Di Amerika, model citizen science salah satunya digunakan dalam pemantauan nyamuk di Baltimore melalui program bernama Mosquito Stoppers (Jordan, Sorensen, \& Ladeau, 2017).

Di Indonesia, penggunaan model citizen science memang masih tergolong baru. Sejauh penelusuran literatur, belum pernah ada penggunaan model citizen science untuk pemantauan hama seperti yang telah dilakukan di negara maju. Meski begitu, pelibatan masyarakat dalam pemantauan melalui model citizen science sudah pernah dilakukan salah satunya yaitu pada pemantauan burung. Pada tahun 2016, Birdpacker, sebuah kelompok pengamat burung di Taman Nasional Baluran, Jawa Timur menginisiasi pemantauan burung dengan model citizen science. Kelompok ini lebih jauh juga membuat aplikasi berbasis android bernama Burungnesia untuk memfasilitasi informasi yang diberikan relawan pemantau burung dari seluruh Indonesia (Winasis, Hakim, \& Imron, 2018). Selain itu, juga terdapat program pemantauan sampah bernama Plastic Free Ocean Program yang diinisiasi oleh World Wide Fund for Nature (WWF). Program ini juga menggunakan platform citizen science dalam pendataan sampah. Hasil data tersebut lalu dibuat sebagai basis data time frame untuk tindak lanjut pengurangan sampah plastik di Indonesia.

\section{A. Hasil}

Kegiatan ini merupakan Program Kemitraan Masyarakat dengan petani cabai rawit yang tergabung dalam Kelompok Tani (KT) Huyula sebagai mitra. Adapun dalam pelaksanaannya, terdapat beberapa tahapan yang telah dilaksanakan dalam kegiatan ini, yaitu:

\section{Tahap Ke-1: Persiapan dan Survei Lokasi}

Survei lokasi yang dilakukan pada lokasi lahan pertanaman cabai yang dimiliki oleh para petani dari KT Huyula. Tujuan dari survei adalah untuk mengamati situasi serta potensi wilayah sekitar lokasi mitra, juga untuk melakukan needs assessment yang berhubungan dengan persiapan kegiatan. Dengan begitu, materi-materi pelatihan yang disusun, maupun strategi kegiatan yang dilakukan berdasar pada hasil survei lapangan ini. Untuk survei awal telah dilakukan pendataan yakni:

1. Jumlah luasan lahan cabai yang akan ditanam.

2. Jumlah titik lokasi serta jarak antar titik lokasi penanaman cabai rawit. 
3. Jenis tanaman disekitar yang berpotensi untuk menjadi wadah parasitoid.

4. Kontur tanah dan geografis lokasi tanam.

Selanjutnya juga dilakukan pendataan hasil produksi dan produktivitas cabai tahun sebelumnya. Tujuannya adalah untuk mendapatkan data perbandingan hasil produksi dan produktivitas tahun setelah dilakukan kegiatan PKM ini.

Hasil dari survei lokasi menunjukkan kelayakan lokasi untuk dilakukannya pelatihan. Hanya saja, terdapat beberapa kendala sehingga pelatihan tidak dapat segera dilakukan. Salah satunya yaitu faktor sosio kultur petani, dimana pada saat persiapan petani sedang tidak melakukan penanaman cabai rawit akibat tidak dianggap kondusif untuk melakukan penanaman cabai rawit. Meski begitu, terdapat beberapa hortikultur yang rencananya akan ditanam oleh petani seperti mentimun, bawang merah, dan tomat. Oleh karena itu, terdapat beberapa format pelatihan yang diubah agar bisa sejalan dengan situasi saat itu.

\section{Tahap Ke-2: Penyusunan Materi Pelatihan}

Penyusunan materi pelatihan dengan metode teknologi tepat guna dalam pemantauan hama kutu kebul yang sederhana. Kegiatan awal ini dilakukan oleh tim pelaksana yang terdiri dari dua akademisi dan dua mahasiswa dari Universitas Ichsan Gorontalo. Adapun materi yang dibawakan oleh tim pelaksana yaitu sebagai berikut:

1. Pengenalan hama kutu kebul dan musuh alaminya (serangga parasitoid dan predator yang mampu mengendalikan populasi hama).

Pada materi pertama ini, diperlihatkan gambar kutu kebul, musuh alami dan gejala serangan hama kutu kebul kepada petani berdasarkan referensi penelitian-penelitian sebelumnya. Selain itu, mengenalkan secara langsung kutu kebul yang terdapat pada daun tanaman cabai.

2. Cara mengidentifikasi kutu kebul (B. tabaci)

Kutu kebul pada pertanaman dapat ditemukan pada bagian bawah daun. Tubuhnya berwarna kuning, tetapi bagian sayapnya tertutup oleh lilin tepung yang berwarna putih.

3. Cara membuat alat perangkap kutu kebul

Materi ini yaitu pelatihan pembuatan perangkap kutu kebul dengan perangkap lengket kuning (Yellow Sticky Trap)

Adapun perangkap kuning yang digunakan yaitu dibuat secara manual dengan bahanbahan yang mudah ditemukan seperti botol bekas, lem tikus, dan cat kuning. Penggunaan botol plastik bekas yang diberi cat kuning dipasang dengan bantuan bambu atau kayu di antara tanaman.

\section{Tahap Ke-3: Pelatihan Pemantauan, Pencegahan dan Pengendalian Hama Kutu Kebul}

Setelah penyusunan materi pelatihan, aktifitas berikutnya adalah pelaksanaan pelatihan pemantauan, pencegahan dan pengendalian hama kutu kebul. Pelatihan dilakukan dengan menggunakan materi yang telah disusun pada Tahap ke-2. Pelatihan ini dibagi tiga sesi, dimana sesi-1 yaitu mengenai pengenalan hama kutu kebul termasuk ciri-ciri serta penanggulangannya. Lalu pada sesi-2, yaitu praktek pembuatan dan pemasangan alat perangkap yellow sticky trap, dimana petani mempelajari cara membuat perangkap hama kutu kebul. Kemudian pada sesi-3, peserta belajar mengenai prosedur field work, yakni pengamatan, pencatatan, serta input data.

Pelatihan ini dilakukan selama 1 hari penuh dimana lokasi pelatihan mengambil tempat di rumah ketua KT Huyula yakni Bapak Wenas Sani. Pada lokasi pelatihan tersedia pelataran dan halaman rumah yang cukup luas untuk dilakukan pelatihan, juga berdekatan dengan lokasi penanaman. Adapun jumlah peserta pelatihan adalah 8 orang petani cabai rawit KT Huyula, 1 
orang penyuluh pertanian, 1 orang fasilitator Read-Si. Pemateri berjumlah 2 orang dari Fakultas Pertanian pada Universitas Ichsan Gorontalo, dibantu oleh 2 orang mahasiswa. Terdapat dua hasil dalam kegiatan ini adalah pelatihan penanggulangan hama kutu kebul, serta database yang disusun bersama oleh petani.

Pelatihan penanggulangan hama kutu kebul dilakukan dalam bentuk sekolah lapang (field school). Hasil pertama kegiatan ini adalah tersedianya pelatihan penanggulangan hama kutu kebul bagi petani yang berguna untuk meningkatkan kemampuan petani dalam menurunkan serangan hama dan meningkatkan produktivitas cabai rawit. Adapun pelatihan yang dilakukan, sebagaimana disepakati oleh tim pelaksana dan mitra adalah dalam bentuk sekolah lapang (field school) sebab bentuk tersebut paling tepat untuk mendemonstrasikan teknologi tepat guna yang ditawarkan kepada petani mitra.

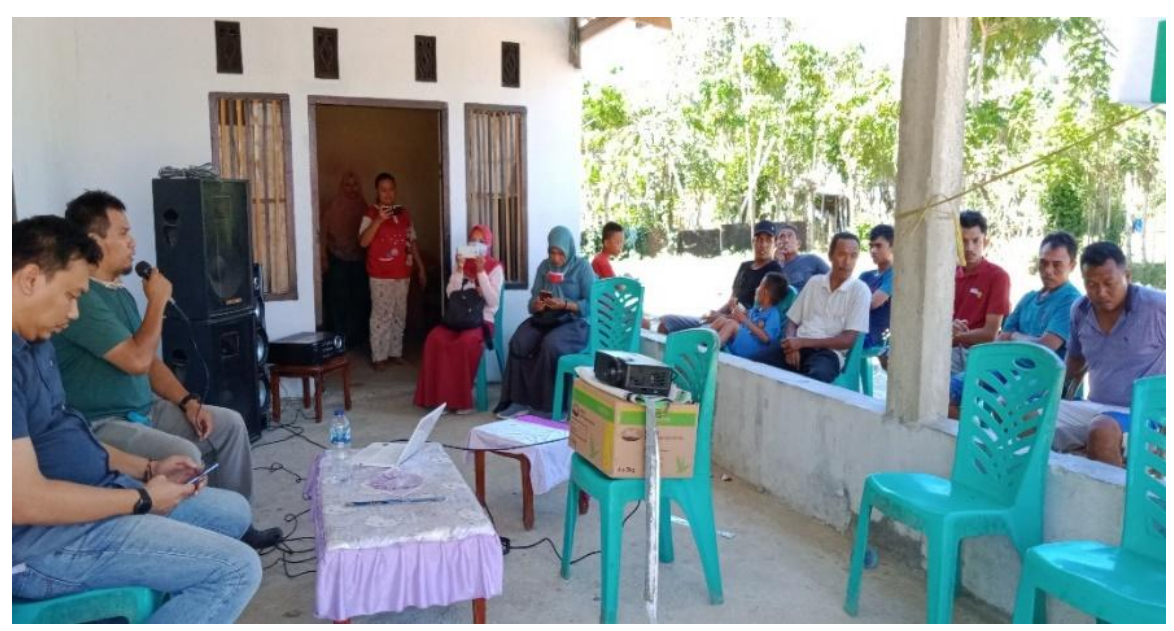

Gambar 1. Pemberian materi dan demonstrasi

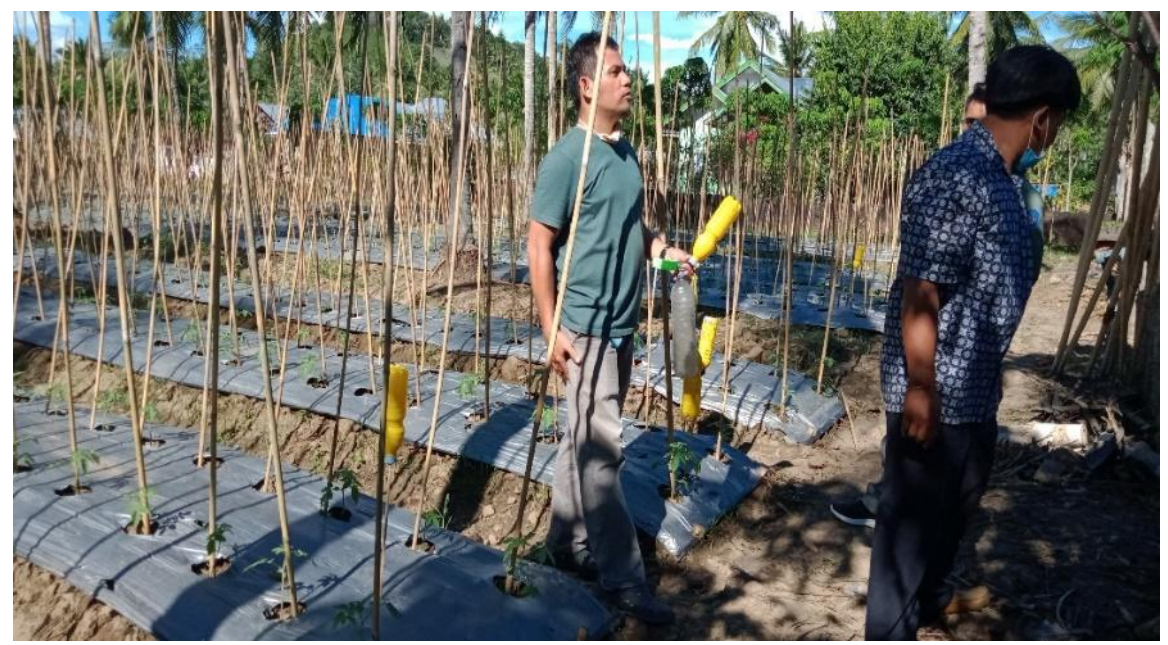

Gambar 2. Pemasangan perangkap di lahan 


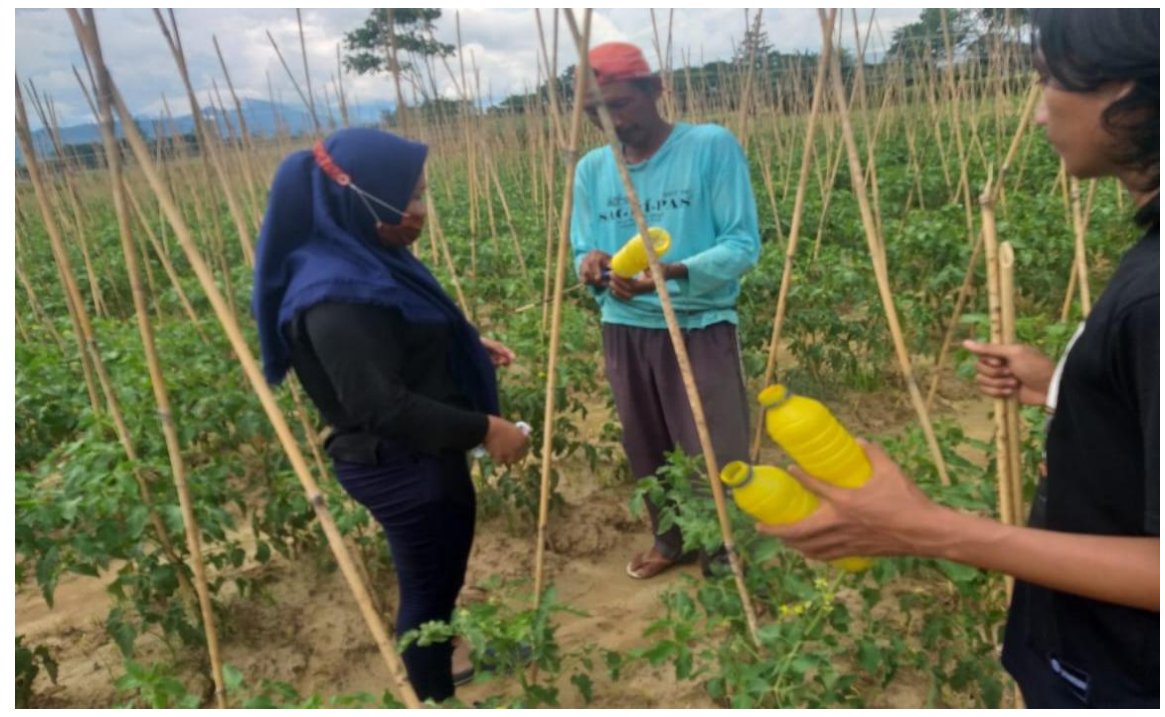

Gambar 3. Praktek pemasangan di lahan

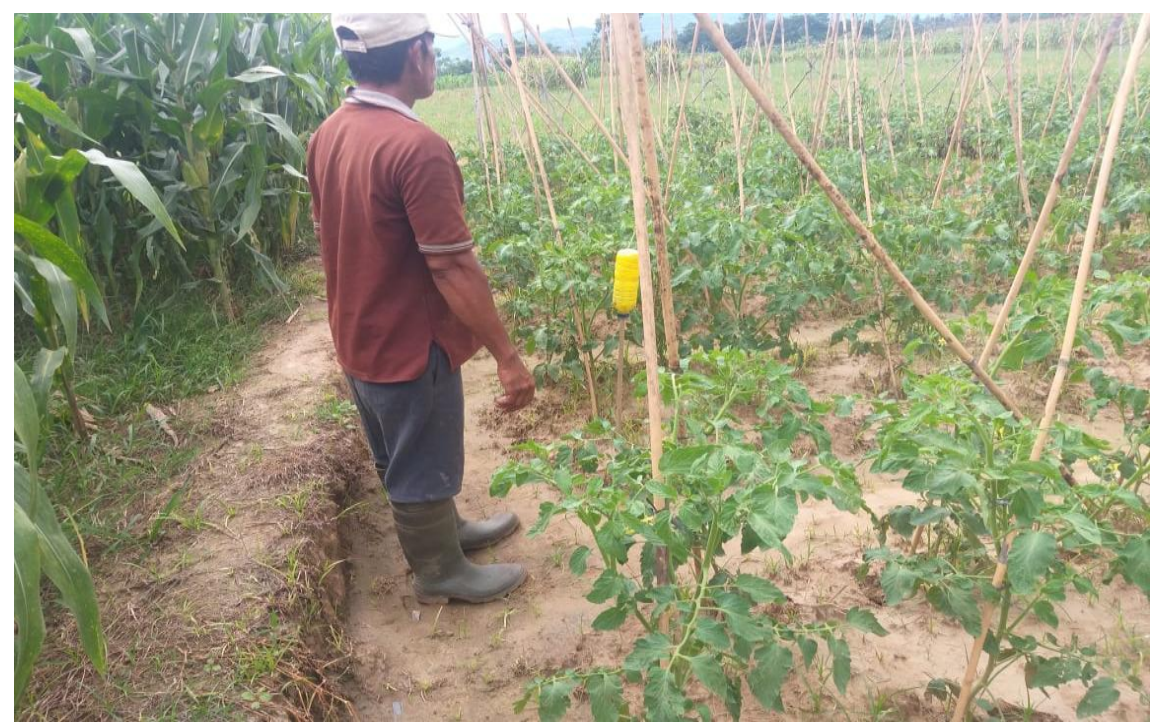

Gambar 4. Pemantauan secara berkala

Pelatihan dilakukan dengan tiga tahap yaitu pemberian materi sekaligus demonstrasi pembuatan dan pemasangan perangkap likat kuning (yellow sticky trap) di lahan petani sebagaimana terlihat pada gambar 2, 3, dan 4. Pemasangan perangkap dilakukan di tiga lahan yang merupakan lokasi petani anggota KT Huyula. Adapun komoditas pada tiga lahan tersebut berbeda-beda yaitu tomat (lahan A), cabai rawit (lahan B), dan mentimun (lahan C). Kemudian pada tahap berikutnya, petani dibantu oleh mahasiswa melakukan pengamatan dan pencatatan tentang jumlah hama yang tertangkap pada perangkap.

\section{Persiapan database pendataan oleh petani}

Hasil berikutnya dalam kegiatan ini adalah tersedianya sistem database awal untuk menampung pendataan pengamatan hama kutu kebul yang dapat dimanfaatkan kedepannya oleh petani maupun stakeholder lainnya. Dalam hal ini, tim pelaksana membuat sistem digital untuk pendataan hama kutu kebul yang terpantau selama musim tanam. Pendataan tersebut 
disesuaikan dengan siklus musim yaitu dalam bentuk Minggu Setelah Tanam (MST) selama 10 minggu (MST 10) sebagaimana terlihat pada Gambar 5. Pencatatan dilakukan secara manual dan diinput pada Google Form.

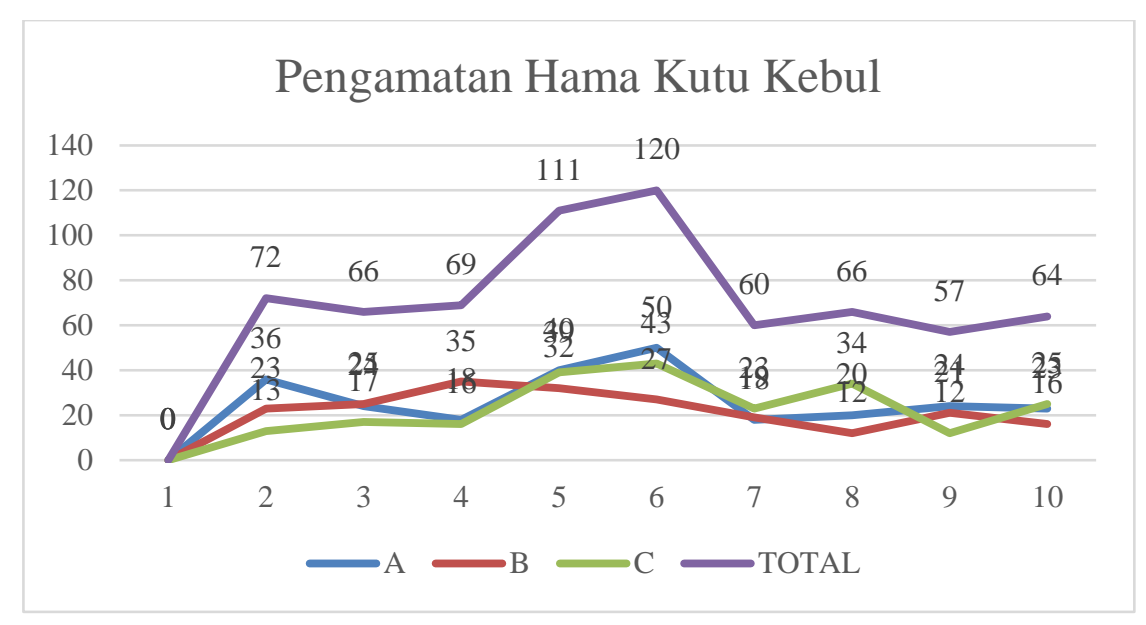

Gambar 5. Hasil rekapitulasi pengamatan di tiga lokasi

Gambar 5 menunjukkan hasil pencatatan yang dilakukan oleh petani di tiga lokasi yang berbeda. Lahan A merupakan lokasi pemasangan pada komoditas tomat, lahan B pada cabai rawit, dan lahan $\mathrm{C}$ pada komoditas mentimun. Data yang terlihat menunjukkan bahwa serangan kutu kebul cukup banyak terjadi pada MST5 dan MST6 utamanya pada tomat dan mentimun, sementara pada lahan cabai rawit banyak terjadi serangan pada MST4. Hasil rekap data ini dibahas dan diperlihatkan kepada peserta kelompok tani sehingga petani turut melihat hasil partisipasi dalam pemantauan dengan skema citizen science.

\section{B. Pembahasan}

Kegiatan ini memberikan pemahaman kepada petani mengenai pentingnya penggunaan perangkap kuning untuk mengurangi serangan hama kutu kebul. Selain itu, kegiatan ini juga memberikan keterampilan kepada petani agar dapat membuat dan menggunakan perangkap kuning sehingga lahan pertanian dapat lebih terjaga. Adapun pengambilan data dilakukan dengan menggunakan kuisioner evaluasi dengan membandingkan pertanyaan retrospektif. Aspek yang diukur adalah aspek pengetahuan dan keterampilan. Untuk aspek pengetahuan, evaluasi diakukan dengan menanyakan pemahaman tentang kegunaan perangkap likat kuning, baik sebelum (pre) maupun setelah (post) kegiatan. Adapun untuk aspek keterampilan, evaluasi dilakukan dengan menanyakan pemahaman peserta terhadap cara pembuatan perangkap likat kuning, baik sebelum (pre) maupun setelah (post) kegiatan.

Peserta diwawancarai setelah kegiatan menggunakan kuisioner sebagai bagian dari evaluasi kegiatan dengan metode pre and post test.. Seluruh peserta ( 8 orang) terlibat dalam evaluasi ini dengan menggunakan indikator pilihan jawaban dengan skala Likert yaitu Sangat Tidak Paham (poin 1), Tidak Paham (2), Biasa saja (3), Paham (4), dan Sangat Paham (5). Hasil evaluasi dengan penggunaan pre-test dan post-test menunjukkan bahwa terjadi peningkatan yang cukup signifikan mengenai pengetahuan maupun keterampilah petani dalam penggunaan perangkap kuning untuk mencegah serangan hama kutu kebul di lahan. Hal tersebut mengindikasikan bahwa kegiatan ini memberikan hasil yang sangat baik dalam hal luaran pengetahuan maupun keterampilan. Selain indikator kuantitatif tersebut, hasil FGD pada tahapan evaluasi juga menunjukkan bahwa petani sebagai peserta merasa terbantu dengan 
adanya kegiatan ini. Petani menunjukkan ketertarikan utamanya dalam penggunaan alat-alat sederhana (botol plastik bekas, cat, dan lem tikus) yang mudah diperoleh disekitar mereka sehingga dapat dibuat dengan mudah.

Kegiatan ini memberikan dampak baik jangka pendek maupun jangka menengah dan panjang bagi petani hortikultura. Sebelum kegiatan, petani belum mengetahui bahwa mereka dapat membuat sendiri perangkap sederhana dengan menggunakan bahan yang mudah ditemukan disekitar dan memberikan dampak yang baik bagi tanaman mereka. Itulah sebabnya, sebelum kegiatan ini cukup banyak hama yang menyerang tanaman dan bahkan mengakibatkan gagal panen pada Tahun 2018. Setelah kegiatan ini, petani menyadari pentingnya pemantauan hama dan juga memahami cara pembuatan perangkap untuk menanggulangi hama kutu kebul sehingga hasil panen dapat dimaksimalkan. Lebih lengkap mengenai bagaimana kegiatan ini memberikan gambaran sebelum, sesudah, maupun dampak jangka panjang kegiatan ini terdapat pada Gambar 6.

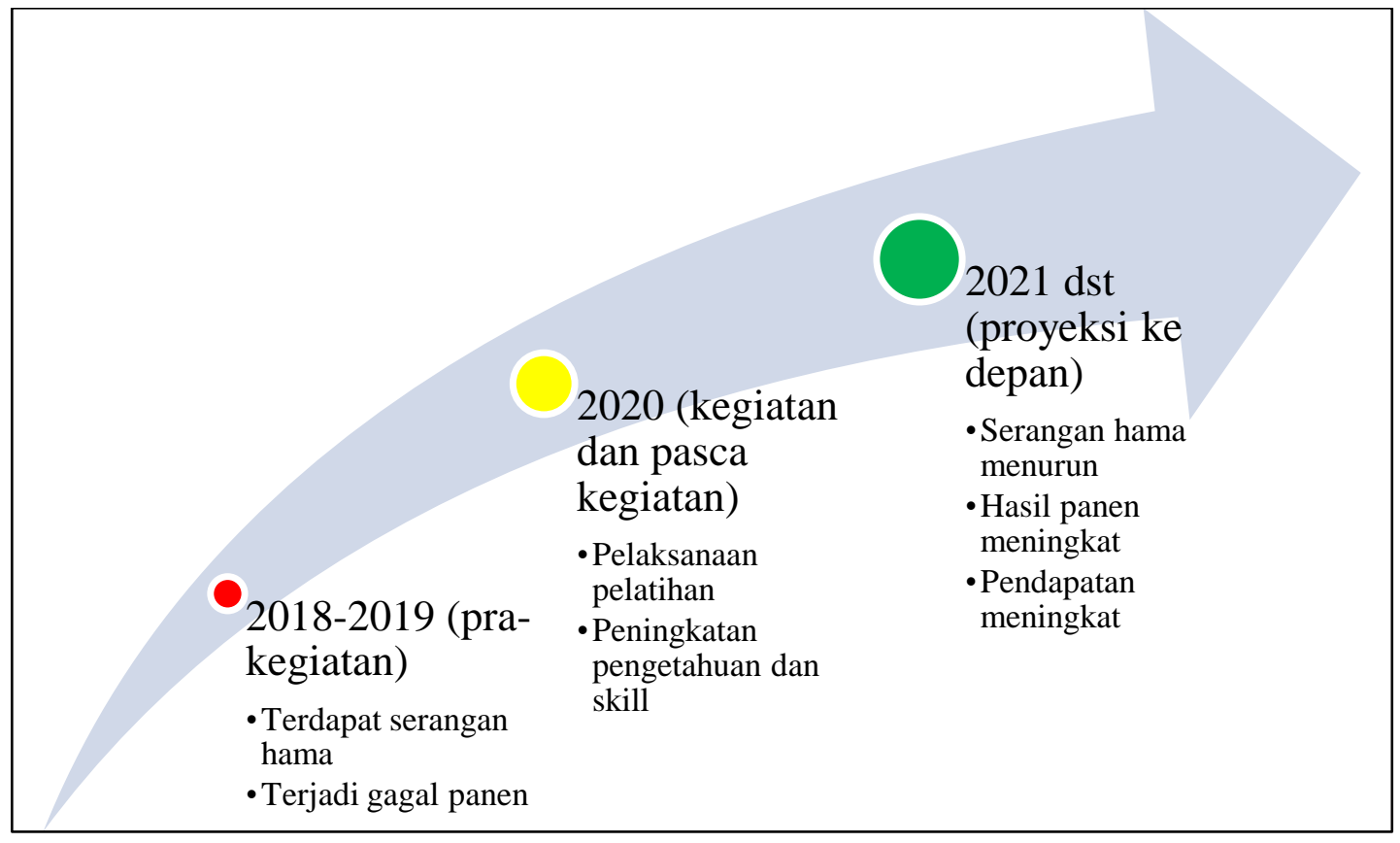

Gambar 6. Road Map hasil kegiatan

\section{Dampak Ekonomi dan Sosial}

Outcome dari kegiatan ini terbagi atas jangka pendek (short-term outcomes), jangka menengah (mid-term outcoms), dan jangka panjang (long-term outcomes). Mempertimbangkan bahwa kegiatan ini sementara berjalan, maka dampak jangka panjang belum dapat terukur. Adapun outcomes jangka pendek yang tercapai terlihat pada Tabel 1.

Tabel 1. Outcomes kegiatan

\begin{tabular}{|c|c|c|}
\hline Aspek & Sebelum & Setelah \\
\hline $\begin{array}{l}\text { Pengetahuan mengenai } \\
\text { pemantauan hama kutu } \\
\text { kebul }\end{array}$ & $\begin{array}{l}\text { Mitra belum mengetahui karakter hama } \\
\text { kutu kebul sehingga tidak mampu } \\
\text { mengidentifikasi hama kutu kebul } \\
\text { maupun hama lainnya. }\end{array}$ & $\begin{array}{l}\text { Mitra telah mengetahui karakter hama } \\
\text { kutu kebul sehingga mampu } \\
\text { mengidentifikasi hama kutu kebul } \\
\text { maupun hama lainnya. }\end{array}$ \\
\hline
\end{tabular}




\begin{tabular}{|l|l|l|}
\hline $\begin{array}{l}\text { Kesadaran mengenai } \\
\text { pentingnya partisipasi } \\
\text { dalam pengendalian hama }\end{array}$ & $\begin{array}{l}\text { Mitra belum menyadari pentingnya } \\
\text { partisipasi petani dalam pengendalian } \\
\text { hama. }\end{array}$ & $\begin{array}{l}\text { Mitra telah menyadari pentingnya } \\
\text { partisipasi petani dalam pengendalian } \\
\text { hama. }\end{array}$ \\
\hline $\begin{array}{l}\text { Pengetahuan mengenai } \\
\text { pembuatan yellow sticky } \\
\text { trap }\end{array}$ & $\begin{array}{l}\text { Mitra belum mengetahui pembuatan } \\
\text { perangkap kuning (yellow sticky trap) } \\
\text { untuk mengendalikan hama kutu kebul } \\
\text { maupun hama lainnya. }\end{array}$ & $\begin{array}{l}\text { Mitra telah mengetahui pembuatan } \\
\text { perangkap kuning (yellow sticky trap) } \\
\text { untuk mengendalikan hama kutu kebul } \\
\text { maupun hama lainnya. }\end{array}$ \\
\hline
\end{tabular}

Sebagai upaya untuk keberlanjutan kegiatan ke depan, perlu untuk mempertimbangkan saran yakni:

1. KT Huyula untuk dapat melanjutkan kegiatan pengendalian dan pemantauan hama kutu kebul baik pada tanaman cabai rawit maupun komoditas lainnya.

2. KT Huyula untuk dapat bermitra dengan kegiatan di tingkat daerah yaitu Read-Si untuk pengembangan kegiatan ke depan.

3. Pemerintah Daerah agar dapat mendukung keberlanjutan kedepan berupa kemitraan dengan KT Huyula maupun Universitas Ichsan Gorontalo sehingga kegiatan serupa dapat direpliaksikan di daaerah lain.

\section{Simpulan}

Kegiatan pelatihan penanggulangan hama kutu kebul merupakan kegiatan yang melibatkan masyarakat dalam pemantauan hama secara seksama berbasis pengetahuan (citizen science). Metodologi yang dilakukan adalah pelatihan penanggulangan kutu kebul melalui pembuatan perangkap likat kuning (yellow sticky trap) yang sederhana dalam bentuk demonstrasi lapangan dan pemantauan berkala. Pelatihan penanggulangan hama kutu kebul dilakukan dalam bentuk sekolah lapang (field school). Kegiatan ini memberikan kontribusi bagi pengetahuan dan keterampilan bagi masyarakat petani dalam penanggulangan hama kutu kebul baik pada cabai rawit maupun sayuran lainnya.

\section{Ucapan Terima Kasih}

Kegiatan ini terlaksana melalui pendanaan hibah Simlitabmas oleh Direktorat Jeneral Pendidikan Tinggi, Kementerian Pendidikan Nasional, serta Kementerian Riset dan Teknologi/BRIN.

\section{Daftar Pustaka}

Andriani, I., \& Yuniarsih, E. T. (2020). Technology innovation of chili in West Sulawesi. Jurnal Agercolere, 2(2), 37-44. https://doi.org/10.37195/jac.v2i2.106

Badan Pusat Statistik. (2019). Kabupaten Gorontalo Dalam Angka 2018. Jakarta.

Indriani, R., Darma, R., Musa, Y., Tenriawaru, A. N., \& Arsyad, M. (2020). Policy design of cayenne pepper supply chain development. Bulgarian Journal of Agricultural Science, 26(3), 499-506.

Jordan, R. C., Sorensen, A. E., \& Ladeau, S. (2017). Citizen Science as a Tool for Mosquito Control. Journal of the American Mosquito Control Association, 33(3), 241-245. https://doi.org/10.2987/17-6644r.1 
Loglio, G., Formato, G., Pietropaoli, M., Jannoni-Sebastianini, R., Carreck, N., \& van der Steen, J. (2019). An Innovative Home-Made Beebread Collector as a Tool for Sampling and Harvesting. Bee World, 96(1), 16-18. https://doi.org/10.1080/0005772x.2018. 1556905

Mas'ud, A. (2002). Efektifitas trap warna terhadap keberadaan serangga pada pertanaman budidaya cabai di Kelurahan Sulamadaha Pulau Ternate. Journal of Chemical Information and Modeling, 53, 159-165.

Prasannath, K., Dharmadasa, N., Menike, N., \& De Costa, D. M. (2020). Evaluation of the effects of an eco-friendly crop protection system on management of whitefly-vectored chilli leaf curl virus disease in Sri Lanka. Phytoparasitica, 48(1), 117-129.

Susanti, D., Widyastuti, R., \& Sulistyo, A. (2015). Aktivitas antifeedant dan antioviposisi ekstrak daun tithonia terhadap kutu kebul. Agrosains: Jurnal Penelitian Agronomi, 17(2), 33-38.

Tuhumury, G. N. C., \& Amanupunyo, H. R. (2018). Kerusakan Tanaman Cabai Akibat Penyakit Virus Di Desa Waimital Kecamatan Kairatu. Agrologia, 2(1).

Viana, C. D. N., Hartono, S., \& Waluyati, L. R. (2017). Volatility Analysis on Producer Price of Red Pepper and Cayenne Pepper in West Java Province Indonesia. Agro Ekonomi, 28(2), 157-169.

Winasis, S., Hakim, L., \& Imron, M. A. (2018). The Utilization of Burungnesia to Detect Citizen Scientist Participation Preference in Birding Sites Observation in Java Island. Journal of Indonesian Tourism and Development Studies, 6(1), 49-54. https://doi.org/10.21776/ub.jitode.2018.006.01.07 